\title{
KERAGAAN ASPEK TEKNIS UNIT TEKNOLOGI PENANGKAPAN IKAN KURAU DI PAMBANG PESISIR KABUPATEN BENGKALIS PROVINSI RIAU
}

\author{
PERFORMANCE TECHNICAL ASPECTS OF FISHING TECHNOLOGY UNIT OF \\ KURAU IN THE COASTAL PAMBANG BENGKALIS DISTRICT RIAU PROVINCE
}

\author{
Muhammad Natsir Kholis ${ }^{1}$, Ronny I Wahju ${ }^{2}$, Mustaruddin ${ }^{2}$ \\ ${ }^{1}$ Program Studi Teknologi Perikanan Laut, Sekolah Pascasarjana \\ ${ }^{2}$ Departemen Pemanfaatan Sumberdaya Perikanan, \\ Fakultas Perikanan dan Ilmu Kelautan, Institut Pertanian Bogor \\ Korespondensi : kholis2336@gmail.com, rwahyu06@gmail.com,musm03@yahoo.com
}

\begin{abstract}
Kurau fish (Eleutheronema tetradactylum) is one type of fish that has economic value and importance in the Coastal Pambang Bengkalis District. This study aimed to analyze the technical aspects and economy aspects (financial) of each unit of fishing technology kurau in Coastal Pambang. Data collection was carried out from July to September 2016 in the Coastal Pambang Bengkalis district Riau Province by using the survey method. The analytical method used is descriptive and financial analysis by calculating the NPV, IRR, PP and BCR. Results of research show that characteristics fishing technology unit of kurau in Pambang Coastal for drift bottom gill net and bottom gill net use webbing made of PA (Polyamide) and nylon the mesh size used measuring 2.5 to 7 inches and boat sizes ranging from 6 to $12 \mathrm{~m}$. while mini longline and fishing line using the main strap nylon 110, hook numbered 6 and 7, with fish bait Cbirocentrus dorab, mackerel, Trichiurus lepturus, shrimp and Harpodon neherous. The size of the boat used ranges from 6 to $8 \mathrm{~m}$. While Results of research show analysis economy ( financial) that all unit fishing kurau technology in Pambang Coastal to be developed with a positive NPV, IRR exceeds the interest rate specified bank and BCR $>1$.
\end{abstract}

Keyword: economic aspect, kurau fish, Pambang coastal, technic aspect

\begin{abstract}
ABSTRAK
Ikan kurau (Eleutheronema tetradactylum) merupakan salah satu jenis ikan yang mempunyai nilai ekonomi penting di Pambang pesisir Kabupaten Bengkalis. Penelitian ini bertujuan untuk menganalisis aspek teknis dan ekonomi (finansial) dari setiap unit teknologi penangkapan ikan kurau di Pambang pesisir. Pengumpulan data dilaksanakan pada bulan Juli sampai September 2016 di Pambang pesisir Kabupaten Bengkalis Provinsi Riau dengan metode survei. Metode analisis yang digunakan yaitu analisis deskriptif dan finansial dengan menghitung nilai NPV, IRR, PP dan BCR. Hasil analisis aspek teknis menunjukkan karakteristik unit teknologi penangkapan ikan kurau di Pambang Pesisir untuk jaring kurau dan jaring tangsi menggunakan webbing berbahan PA (Polyamide) dan tangsi, mesh size yang digunakan berukuran 2.5 sampai 7 inci dan ukuran kapal berkisar 6 sampai $12 \mathrm{~m}$. Sedangkan rawai dan pancing menggunakan tali utama berbahan nilon 110, mata pancing bernomor 6 dan 7, dengan umpan ikan parang-parang, tenggiri, layur, udang dan lomek. Ukuran kapal yang digunakan berkisar 6 sampai $8 \mathrm{~m}$. Sedangkan hasil analisis ekonomi (finansial) menunjukkan bahwa seluruh unit teknologi penangkapan ikan kurau di Pambang Pesisir layak untuk dikembangkan dengan nilai NPV yang positif, nilai IRR melebihi bunga suku bank yang ditetapkan dan BCR $>1$.
\end{abstract}

Kata kunci: aspek ekonomi, aspek teknis, ikan kurau, Pambang pesisir 


\section{PENDAHULUAN}

Pambang pesisir merupakan salah satu desa yang ada di Kabupaten Bengkalis Provinsi Riau. Kehidupan sosial ekonominya sangat tergantung pada hasil laut, sehingga sebagian besar masyarakatnya berprofesi sebagai nelayan, dan ekonomi rakyat sangat tergantung pada hasil laut. Tercatat 276 jiwa masyarakatnya bermata pencaharian nelayan (DKP Kabupaten Bengkalis 2014).

Komoditas unggulan yang dimiliki perairan Pambang pesisir yaitu ikan kurau (Eleutheronema tetradactylum). Ikan ini merupakan ikan primadona, karena tingginya harga yang mencapai Rp.100.000/ kg. Ikan ini dapat dieksploitasi dengan beragam unit teknologi penangkapan, biasanya nelayan desa Pambang pesisir menggunakan beberapa jenis alat tangkap yaitu: jaring kurau (drift bottom gillnet), jaring tangsi (bottom gillnet/mid bottom gillnet), rawai (bottom mini longline) dan pancing (fishing line).

Menurut Rengi (2015) menyatakan bahwa saat ini ikan kurau telah mengalami overfishing sebesar $33.42 \%$ dari tingkat pemanfaatan optimal upayanya sebesar 141.949 /tahun, optimal biomass 15.321 .34 ton dan optimal menangkap 4.407.72 ton. Melihat data dan kondisi ikan kurau saat ini, tentu menjadi masalah besar bagi nelayan karena akan memengaruhi usaha yang selama ini mereka jalankan. Tidak menutup kemungkinan nelayan yang sudah turun-temurun melaut berganti profesi di daratan. Sebaiknya Pemanfaatan sumberdaya perikanan yang berkelanjutan sangat erat kaitannya dengan aspek teknis dan ekonomi (finansial) sebagai penopang kehidupan masyarakat yang bergantung hidup di laut.

Aspek teknis sangat berperan besar dalam usaha penangkapan ikan kurau maka dari itu perlu kajian tentang aspek teknis dari beberapa unit teknologi penangkapan ikan kurau yang beroperasi di Pambang pesisir. Minimnya pengetahuan nelayan terhadap keragaan dari masing-masing unit teknologi penangkapan ikan kurau menyebabkan lambatnya nelayan merespon dinamika perubahan perikanan kurau, sehingga terjadi kecemburuan sosial akibat perbedaan hasil tangkapan yang mencolok.

Penelitian ini bertujuan mengidentifikasi dan menganalisis karakteristik aspek teknis dan aspek ekonomi (finansial) dari setiap unit teknologi penangkapan ikan kurau di Pambang pesisir. Harapan ke depan tata kelola usaha dan manajemen operasi penangkapan ikan kurau lebih efisien dalam pengembangan usahanya.

\section{METODE PENELITIAN}

Penelitian ini dilaksanakan pada bulan Juli sampai September 2016 di Desa Pambang Pesisir Kabupaten Bengkalis Provinsi Riau. Peta lokasi penelitian disajikan pada Gambar 1.
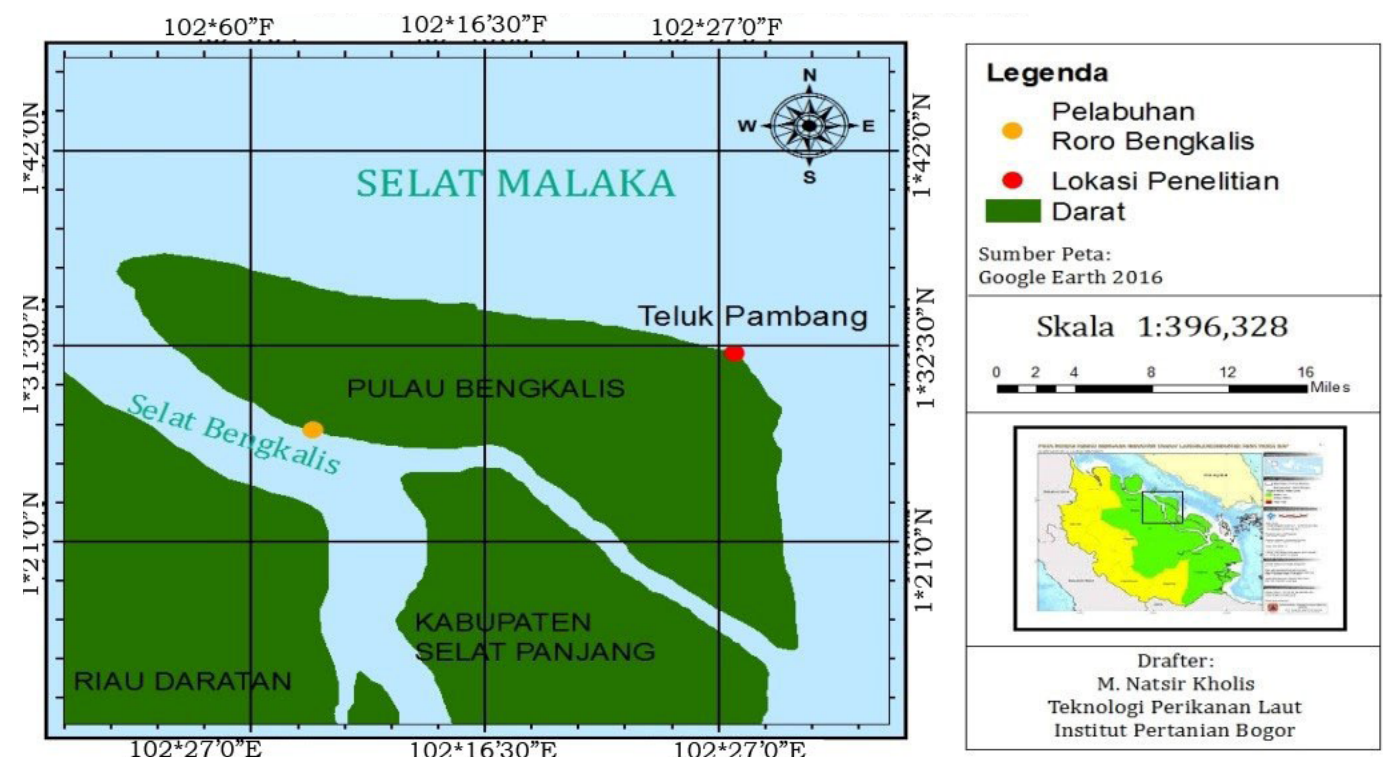

Gambar 1. Peta lokasi penelitian 
Jenis data yang dikumpulkan pada penelitian ini yaitu: data primer dan data sekunder. Data primer terdiri dari hasil penjualan ikan, investasi, biaya tetap dan biaya tidak tetap. Sedangkan data sekunder terdiri dari: times series produksi hasil tangkapan, times series jumlah alat tangkap, times series nelayan dan times series armada penangkapan. Metode yang digunakan dalam pengambilan data yaitu metode survei dengan teknik random sampling, dengan kuesioner terstruktur terhadap $10 \%$ dari jumlah responden.

\section{Analisis data}

\section{Net Present Value (NPV)}

NPV yaitu selisih antara Present Value dari investasi dan nilai sekarang dari penerimaan bersih (arus kas operasional maupun arus kas terminal) di masa yang akan datang. NPV digunakan untuk menilai manfaat investasi dengan ukuran nilai kini dari keuntungan bersih. Nilai NPV di hitung menggunakan rumus (Umar 2003; Hermansyah et al. 2013).

$$
N P V=\sum_{t=1}^{n}=1 \frac{C F t}{(1+K) t} I o
$$

Dimana:

$$
\begin{array}{ll}
\text { CFt } & =\text { aliran kas per tahun pada periode } \\
& \mathrm{t} \\
\text { Io } & =\text { investasi awal pada tahun ke-0 } \\
K & =\text { suku bunga (discount factor) } \\
t & =\text { tahun ke- } \\
n & =\text { jumlah tahun }
\end{array}
$$

Jika :

NPV > 1: maka usaha tersebut layak NPV = 0: maka usaha tersebut dapat layak NPV < 1: maka usaha tersebut tidak layak

\section{Benefit Cost Ratio (BCR)}

BCR yaitu perbandingan antara pendapatan kotor atau hasil penjualan dengan biaya total yang dikeluarkan. Nilai BCR dapat dihitung menggunakan rumus (Umar 2003; Hermansyah et al. 2013):

$$
B C R=\frac{P V \text { Benefit }}{P V \text { Cost }}
$$

Jika:

BCR $>1$ maka usaha menguntungkan $\mathrm{BCR}<1$ maka usaha tidak menguntungkan $\mathrm{BCR}=1$ maka usaha impas (hanya balik modal)

Internal Rate of Return (IRR)

Rumus yang digunakan untuk menghitung IRR yaitu (Umar 2003; Hermansyah et al. 2013):

$$
I R R=P_{1}-C_{1}=\left(\frac{P_{2}-P_{1}}{C_{2}-C_{1}}\right)
$$

$$
\begin{aligned}
& \text { Dimana: } \\
& \mathrm{P} 1 \quad=\text { tingkat bunga ke-1 } \\
& \mathrm{P} 2 \quad=\text { tingkat bunga ke-2 } \\
& \mathrm{C} 1 \quad=\text { NPV ke-1 } \\
& \mathrm{C} 2 \quad=\text { NPV ke-2 }
\end{aligned}
$$

Payback Period (PP)

$$
P P=\frac{\text { Nilai Investasi }}{\text { Keuntungan }} \times 1 \text { Tahun }
$$

Pengambilan keputusan :

Semakin cepat waktu PP dibandingkan dengan periode waktu maksimum yang telah ditetapkan, maka usulan proyek usaha akan semakin layak dijalankan. Tingkat pengembalian modal dalam suatu usaha dikategorikan cepat jika nilai $\mathrm{PP}<3$ tahun, tingkat pengembalian modal dikategorikan sedang jika nilai $\mathrm{PP}<5$ tahun, sedangkan yang dikatakan dalam kategori tingkat pengembalian lambat jika nilai $\mathrm{PP}>5$ tahun (Umar 2003; Hermansyah et al. 2013).

\section{HASIL DAN PEMBAHASAN}

\section{Aspek teknis}

Hasil pengamatan di lapangan menunjukkan unit teknologi penangkapan ikan yang digunakan nelayan Pambang Pesisir bersifat skala kecil, dan kebanyakan masih menggunakan teknologi yang sederhana. Menurut Wiyono (2011) menyatakan bahwa hampir 90\% kegiatan penangkapan ikan di Indonesia saat ini didominasi oleh perikanan skala kecil, walaupun telah memberikan kontribusi yang signifikan terhadap kondisi sosial ekonomi nelayan. Oleh karena itu perikanan skala kecil semakin dipelajari, mengingat dampaknya yang sangat besar dan perannya sangat memengaruhi ekologi dan ekonomi (De Wysiecki et al. 2016).

\section{Jaring kurau (drift bottom gill net)}

Jaring kurau adalah jaring insang 
hanyut dasar, yang target tangkapan utamanya ikan kurau. Bahan jaring/ webbing alat tangkap jaring kurau ini yaitu PA (Polyamide). Ukuran mesh size yang digunakan nelayan berkisar 5 sampai 7 inci, dengan ukuran kapal 8.5 sampai $12 \mathrm{~m}$. Data spesifikasi unit teknologi penangkapan jaring kurau selengkapnya disajikan pada (Tabel 1) dan kontruksinya disajikan pada (Gambar 2).

Hasil tangkapan jaring kurau merupakan ikan-ikan ekonomis penting, komposisi hasil tangkapan jaring kurau dibagi menjadi tiga yaitu:

1. Target utama: kurau (Eleutherema tectradactylum);

2. Target sampingan: kerapu (Ephinepleus spp.) dan malung (Muraenesox spp.) ;

3. Sampingan: gerut (lates calcalifer), parang (Chirocentrus dorab) tenggiri (Scomberomorus commerson), talang (Chorinemus spp.), debuk/duri (Bagrus nemurus), merah (Lutjanus spp.), senangin (Polynemus spp.), manyung (Arius spp.), pari (Trygon sephen), dan hiu (Shark).

Tabel 1. Spesifikasi alat tangkap jaring kurau

\begin{tabular}{llll}
\hline \multicolumn{3}{c}{ Unit Penangkapan Ikan Kurau } \\
\hline Nama Alat & : Jaring Insang & Kapal & $:$ Kapal Motor \\
Spesifik & $:$ Jaring Hanyut Dasar & L.O.A & $: 8.5-12 \mathrm{~m}$ \\
Daerah operasi & $:$ Selat Malaka & Tonase Kotor & $: 6-10 \mathrm{GT}$ \\
Kondisi Perairan & $:$ Berpasir dan Berlumpur & Mesin & $: 4$ PK Yanmar \\
Ikan Sasaran & $:$ Kurau & BBM & $:$ Solar \\
Bahan Jaring & $:$ PA & ABK & $:$ 3-5 orang \\
Mesh Size & $: 5-7$ Inci & & \\
\hline
\end{tabular}

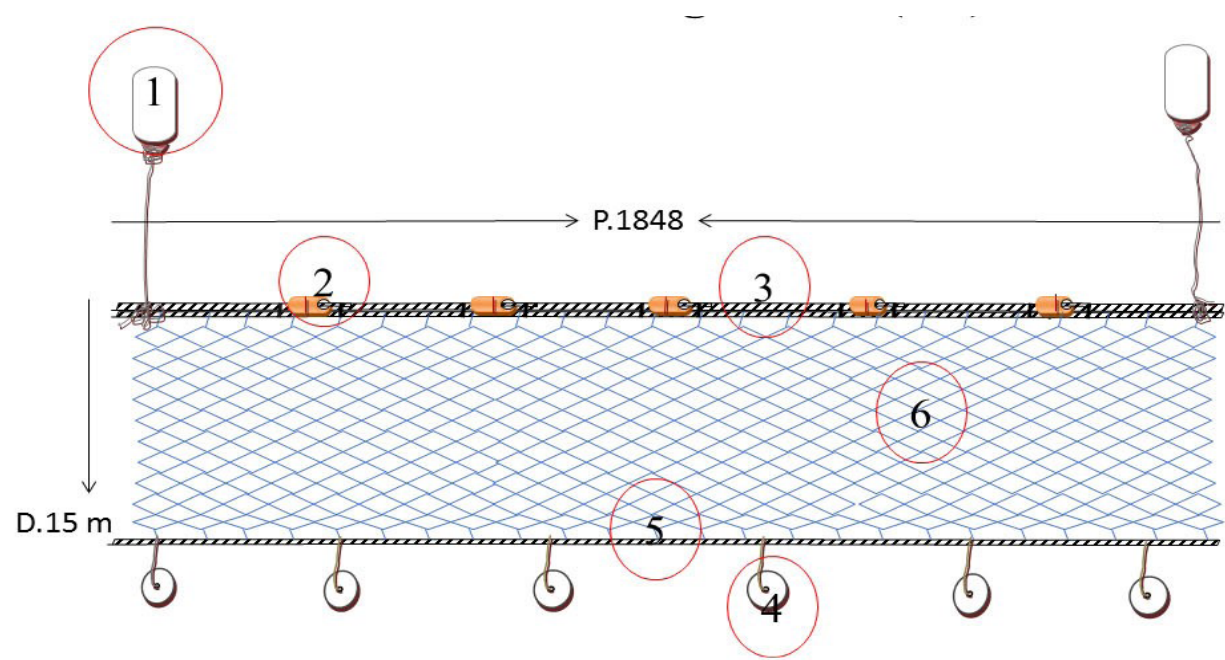

Keterangan :
1. Pelampung tanda
4. Pemberat
2. Pelampung webbing
5. Tali pemberat
3. Tali ris atas dan tali ris bawah
6. Webbing

Gambar 2. Kontruksi jaring kurau 
Jaring tangsi (bottom gill net)

Jaring tangsi adalah jaring insang dasar, yang target tangkapan utamanya ikan kurau, tenggiri dan parang-parang (KTP). Bahan dasar jaring/webbing alat tangkap jaring tangsi yaitu tangsi (tali nilon). Ukuran mesh size yang digunakan nelayan berkisar 2.5-5 inci, dengan ukuran kapal 6-8m. Data spesifikasi unit teknologi penangkapan jaring tangsi selengkapnya disajikan pada (Tabel 2) dan kontruksinya disajikan pada (Gambar 3).

Hasil tangkapan jaring tangsi juga merupakan ikan-ikan ekonomis penting, sama halnya dengan jaring kurau komposisi hasil tangkapan jaring tangsi dibagi menjadi tiga yaitu:

1. Target utama: kurau (Eleutherema tectradactylum), parang (Chirocentrus dorab) dan tenggiri (Scomberomorus commerson).

2. Target sampingan: merah (Lutjanus spp.), senangin (Polynemus spp.) dan malung (Muraenesox spp.).

3. Sampingan: gerut (Lates calcalifer), talang (Chorinemus spp.), debuk/duri (Bagrus nemurus), kerapu (Ephinepleus spp.) dan manyung (Arius spp.).

Tabel 2. Spesifikasi alat tangkap jaring tangsi

\begin{tabular}{llll}
\hline \multicolumn{4}{c}{ Unit Penangkapan Ikan Kurau } \\
\hline Nama Alat & : Jaring Insang & Kapal & $:$ Kapal Motor \\
Spesifik & : Jaring Dasar dan Pertengahan & L.O.A & $: 6-8 \mathrm{~m}$ \\
Daerah operasi & : Selat Malaka & Tonase Kotor & $:$ 3-5 GT \\
Kondisi Perairan & $:$ Berpasir dan Berlumpur & Mesin & $:$ PK Yanmar \\
Ikan Sasaran & $:$ Kurau, Tenggiri dan Parang (KTP) & BBM & $:$ Solar \\
Bahan Jaring & $:$ Tangsi & ABK & $: 2-3$ orang \\
Mesh Size & $: 2.5-5$ Inci & & \\
\hline
\end{tabular}

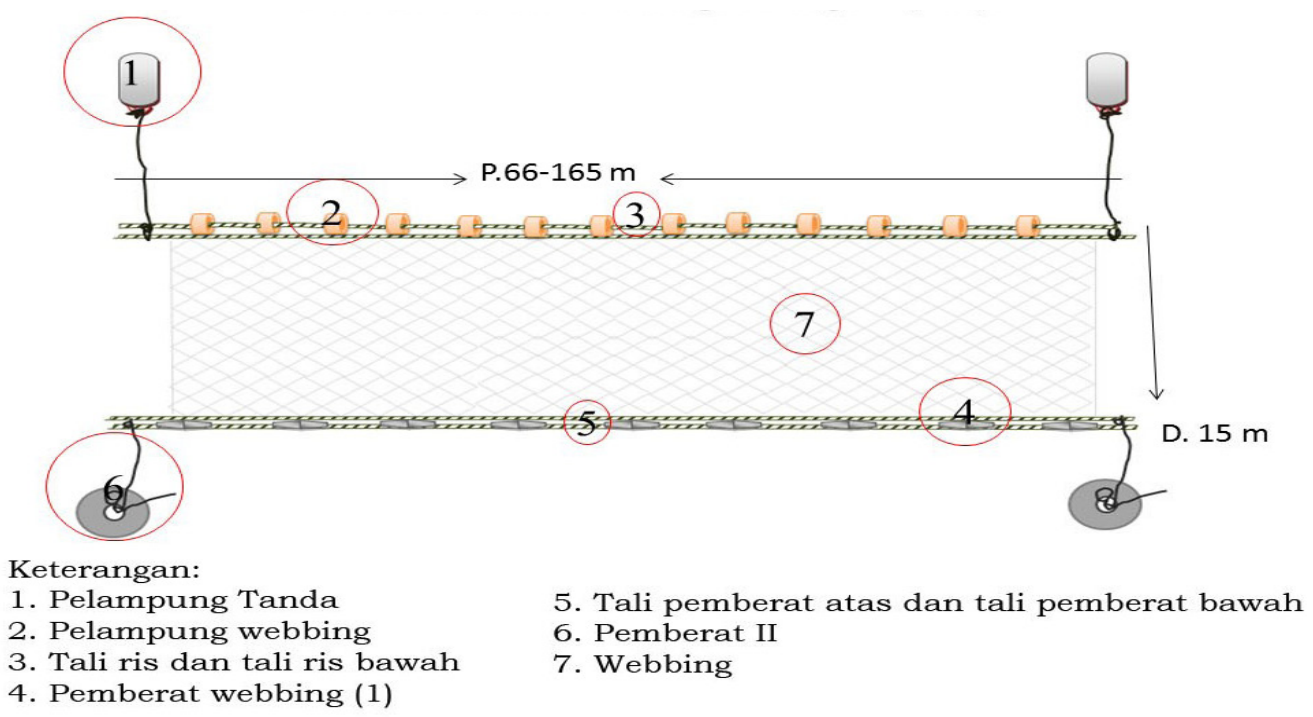

Gambar 3. Kontruksi jaring tangsi 


\section{Rawai (mini longline)}

Rawai adalah untaian pancing yang disusun lurus memanjang ke samping atau kebawah, dengan target tangkapan utamanya ikan kurau. Tali utama rawai di Pambang Pesisir berbahan natuna dan tali cabangnya berbahan tangsi 110 (tali nilon). Mata pancing yang biasa digunakan bernomor 6 dan 7. Sedangkan umpan yang digunakan seperti: Parang-parang, tenggiri, layur, udang dan lomek. Data spesifikasi unit teknologi penangkapan rawai selengkapnya disajikan pada (Tabel 3) dan kontruksinya disajikan pada (Gambar 4).
Hasil tangkapan rawai kurau juga merupakan ikan-ikan ekonomis penting, komposisi hasil tangkapan rawai kurau juga dibagi menjadi tiga yaitu:

1. Target utama: kurau (Eleutherema tectradactylum).

2. Target sampingan: kakap (Lutjanidae spp.), senangin (Polynemus spp.) dan malung (Muraenesox spp.).

3. Sampingan: gerut (Lates calcalifer), talang (Chorinemus spp.), debuk/duri (Bagrus nemurus), merah (Lutjanus spp.), senangin (Polynemus spp.), manyung (Arius spp.), pari (Trygon sephen) dan hiu (Shark).

Tabel 3. Spesifikasi alat tangkap rawai

\section{Unit Penangkapan Ikan Kurau}

\begin{tabular}{llll}
\hline Nama Alat & : Mini Longline & Kapal & : Kapal Motor \\
Spesifik & : Dasar Perairan & L.O.A & $: 6-8 \mathrm{~m}$ \\
Daerah operasi & : Selat Malaka & Tonase Kotor & $:$ 3 GT \\
Kondisi Perairan & : Berpasir dan Berlumpur & Mesin & : Domfeng \\
Ikan Sasaran & $:$ Kurau & BBM & $:$ Solar \\
Umpan & $:$ Parang-parang, tenggiri, layur, & ABK & $:$ 2-3 orang \\
& udang dan lomek & & \\
$\begin{array}{l}\text { Ukuran mata } \\
\text { pancing }\end{array}$ & $:$ Nomor 6 dan 7 & & \\
$\begin{array}{l}\text { Bahan tali } \\
\text { pancing }\end{array}$ & $:$ Tali Utama (Natuna), Tali cabang & & \\
\hline
\end{tabular}

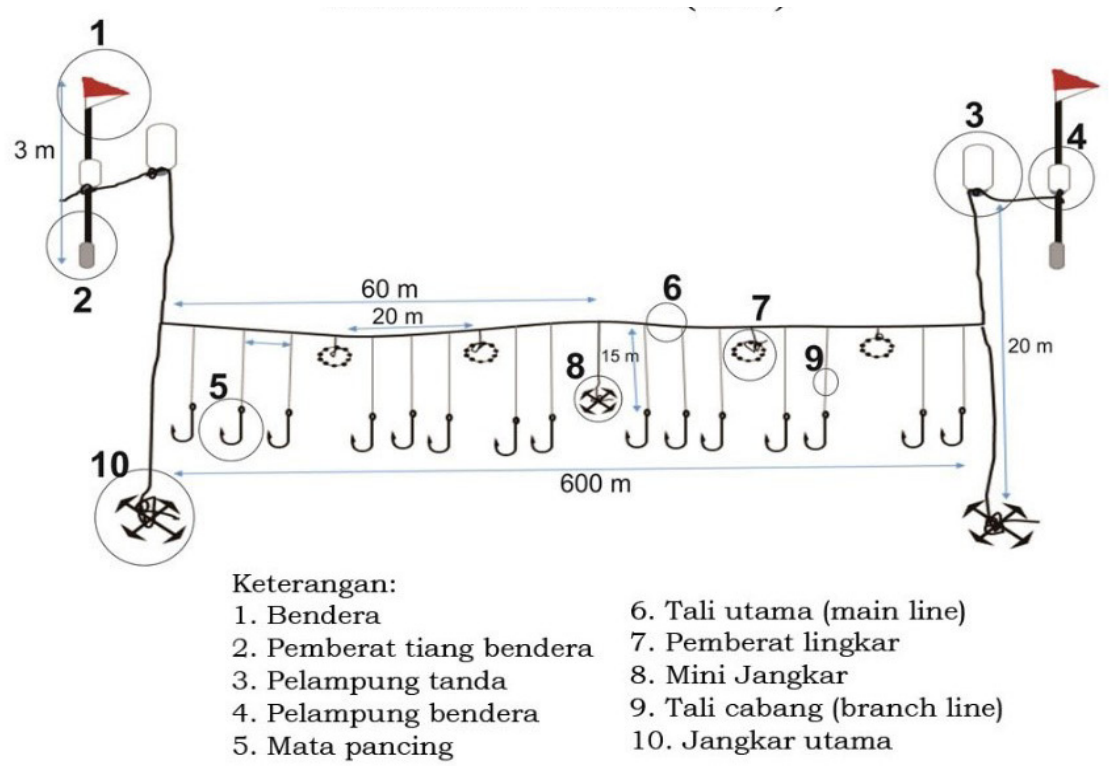

Gambar 4. Kontruksi rawai 


\section{Pancing (fishing line)}

Pancing adalah salah satu alat tangkap ikan yang terdiri dari dua komponen utama, yaitu: tali (line) dan mata pancing (hook). Bagian-bagian pancing terdiri atas joran (rod), gulungan (reel), tali pancing (lines), mata pancing (hook). Namun sesuai dengan jenisnya, pancing dapat dilengkapi pula komponen lain seperti: pemberat (sinker), pelampung (float), dan kili-kili (swivel). Pancing yang digunakan nelayan Pambang Pesisir ada dua jenis yaitu: pancing katrol dan pancing ulur. Dimana nelayan biasanya menggunkan nomor mata pancing berukuran 6 dan 7, dengan umpan seperti: Parang-parang, tenggiri, layur, udang dan lomek. Data spesifikasi unit teknologi penangkapan pancing selengkapnya disajikan pada (Tabel 4) dan kontruksinya disajikan pada (Gambar 5).

Hasil tangkapan pancing juga merupakan ikan-ikan ekonomis penting yang daerah penangkapnnya tidak jauh dari pesisir. komposisi hasil tangkapan pancing dibagi menjadi tiga yaitu:

1. Target utama: kurau (Eleutherema tectradactylum) dan senangin (Polynemus spp.).

2. Target sampingan: kerapu (Ephinepleus spp.) dan kakap (Lutjanidae spp.).

3. Sampingan: gerut (Lates calcalifer), talang (Chorinemus spp.), debuk/duri (Bagrus nemurus), merah (Lutjanus spp.), malung (Muraenesox spp.), belut laut (Petromyzon marinus) dan manyung (Arius spp.).

Tabel 4. Alat tangkap pancing

\begin{tabular}{llll}
\hline \multicolumn{4}{c}{ Unit Penangkapan Ikan Kurau } \\
\hline Nama Alat & $:$ Pancing & Kapal & : Motor Tempel \\
Spesifik & $:$ Katrol dan Non Katrol & L.O.A & $: 3-6 \mathrm{~m}$ \\
Daerah operasi & $:$ Selat Malaka & Tonase Kotor & $:$ 3 GT \\
Kondisi Perairan & $:$ Berpasir dan Berlumpur & Mesin & $:$ Domfeng \\
Ikan Sasaran & $:$ Kurau dan Senangin & BBM & : Solar \\
Umpan & $:$ Parang-parang, tenggiri, layur, & ABK & $: 2-3$ orang \\
& udang dan lomek & & \\
Ukuran mata pancing & $:$ No.6 dan 7 & & \\
Bahan tali pancing & $:$ Tangsi & & \\
\hline
\end{tabular}
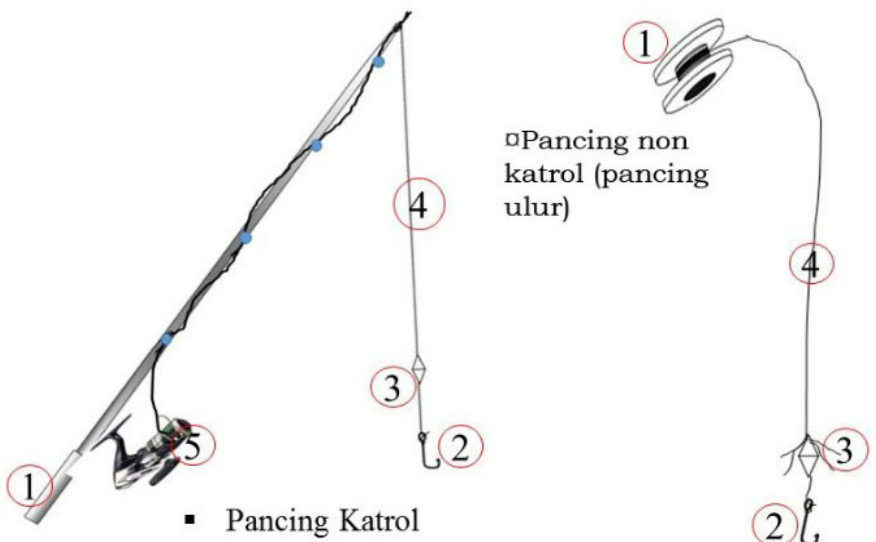

Keterangan:

1. Bendera

2. Pemberat tiang bendera

Keterangan:

1. Rol

3. Pelampung tanda

2. Mata pancing

4. Pelampung bendera

3. Pemberat

4. Tali pancing

Gambar 5. Kontruksi pancing 


\section{Pemasaran dan harga pasar}

Hasil tangkapan nelayan Kabupaten Bengkalis dijual hingga ke luar negeri seperti: ikan kurau, kerapu, senangin, kakap dan malung. Ikan kurau merupakan ikan yang paling tinggi nilai ekonominya, dimana ikan kurau ini di ekspor ke Malaysia bahkan sampai ke Thailand dan Hongkong. Secara umum distribusi pemasaran hasil tangkapan nelayan di Desa Pambang Pesisir disajikan pada (Gambar 6).

Adanya tujuan pasar yang jelas dan harga yang stabil diharapkan mampu membangun sektor perikanan Indonesia yang lebih terstruktur dengan memberikan kontribusi terhadap tiga komponen penting pembangunan nasional, yaitu pertumbuhan ekonomi (pro growth), perluasan lapangan kerja (pro job) dan penurunan tingkat kemiskinan (pro poor). Namun, sampai saat ini pembangunan perikanan tersebut belum secara signifikan memberikan kontribusi ekonomi yang berarti bagi pembangunan dan taraf hidup yang sejahtera bagi nelayan sebagai pelaku usaha (Yafiz 2009).

Menurut Purnomo et al. (2013) ikan hasil tangkapan nelayan terutamaikan kurau berukuran besar biasanya dikumpulkan di dalam coolbox yang telah diberi es batu dan diletakkan di gudang penyimpanan. Setelah ikan terkumpul dalam 4-5 hari, barulah ikan tersebut diambil oleh toke untuk di ekspor ke luar negeri sedangkan ikan hasil tangkapan lainnya akan di ambil oleh pedagang pengumpul untuk langsung dijual di pasar lokal. Kisaran harga ikan di Pambang Pesisir disajikan pada (Tabel 5).

Harga ikan di Pambang Pesisir pada umumnya tergantung musim ikan, ikan kurau dapat mencapai harga dari Rp.100.000 sampai Rp.150.000/kg saat musim penceklik dan pada musimnya hanya berkisar Rp.70.000 sampai Rp.90.000/ kg. Musim ikan kurau cukup sulit untuk diprediksi saat ini, melihat perubahan kondisi cuaca yang tidak menentu (climate change). Menurut penelitian Syaifuddin (2008) menyatakan bahwa musim puncak ikan kurau di Bengkalis yaitu bulan April, Mei dan November. Berbeda halnya menurut Purnomo et al. (2013) menyatakan bahwa musim ikan kurau berada pada musim timur, yaitu terjadi antara bulan JanuariApril.

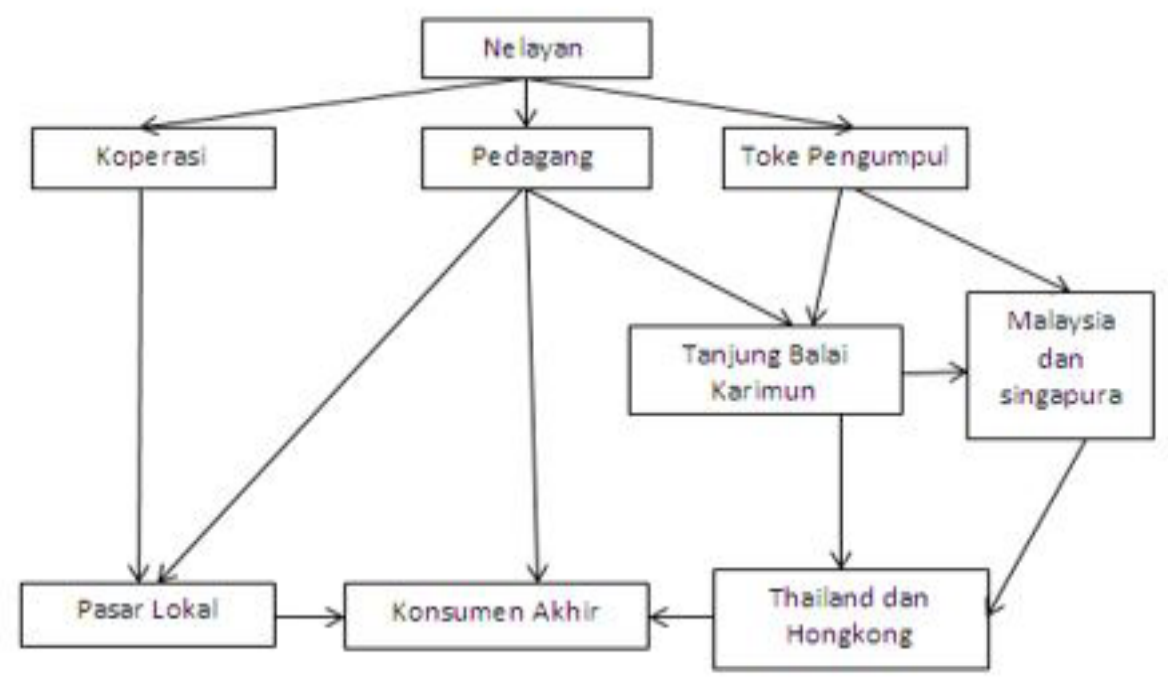

Gambar 6. Distribusi pemasaran hasil tangkapan nelayan di Pambang Pesisir 
Tabel 5. Kisaran harga ikan di Pambang Pesisir tahun 2016

\begin{tabular}{clcr}
\hline No & \multicolumn{1}{c}{ Produk } & Satuan & Harga Jual (Rp) \\
\hline 1 & Kurau & $\mathrm{kg}$ & 100.000 \\
2 & Parang dan Tenggiri & $\mathrm{kg}$ & 15.000 \\
3 & Merah & $\mathrm{kg}$ & 8.000 \\
4 & Senangin dan Senangin & $\mathrm{kg}$ & 20.000 \\
5 & Malung & $\mathrm{kg}$ & 12.000 \\
6 & Gerut, Siakap dan Manyung & $\mathrm{kg}$ & 18.000 \\
7 & Talang & $\mathrm{kg}$ & 7,000 \\
8 & Debuk/Duri & $\mathrm{kg}$ & 10.000 \\
9 & Biyang & $\mathrm{kg}$ & 5.000 \\
10 & Lomek & $\mathrm{kg}$ & 1.500 \\
11 & Layur & $\mathrm{kg}$ & 8.000 \\
12 & Pari & $\mathrm{kg}$ & 3.500 \\
13 & Hiu & $\mathrm{kg}$ & 21.000 \\
\hline
\end{tabular}

\section{Aspek ekonomi}

\section{Permodalan usaha}

Suatu usaha pasti membutuhkan modal awal untuk memulai usahanya. Besar kecilnya modal tergantung dari jenis usaha yang akan dijalankan. Modal dapat dikatakan berhasil apabila dapat memberikan keuntungan secara ekonomis bagi pengusahanya (Pratama et al. 2012). Permodalan usaha penangkapan ikan terdiri dari dua jenis, yaitu: biaya tetap dan biaya tidak tetap. Biaya tetap adalah biaya yang harus dikeluarkan dalam setiap usaha dan tidak tergantung pad Berdasarkan (Tabel 6) unit teknologi penangkapan jaring kurau memiliki modal tertinggi dari ketiga jenis unit teknologi penangkapan ikan kurau lainnya yaitu: Rp. 404.070.000 diikuti rawai sebesar Rp. 183.270.000, jaring tangsi sebesar Rp. 130.470.000 dan pancing sebesar Rp. 80.610.000.

Menurut Wismaningrum (2013) menyatakan bahwa modal merupakan faktor yang utama dalam suatu usaha termasuk usaha penangkapan ikan. Modal sebagai sarana dalam kelancaran proses produksi suatu usaha dalam memperoleh keuntungan kedepannya. Modal yang dibutuhkan dalam usaha penangkapan ikan adalah besarnya investasi dalam bentuk kapal, alat tangkap, mesin kapal, dan peralatan lainnya.

Sedangkan menurut Rohani (2015) menyatakan bahwa Biaya operasional (biaya awal usaha) adalah biaya yang dikeluarkan unit usaha teknologi penangkapan ikan yang terdiri dari biaya tetap dan biaya tidak tetap dalam satu trip, namun juga dapat dihitung menjadi satu bulan dan satu tahun dalam melakukan trip penangkapan.

\section{Pendapatan usaha dan Benefit Cost Ratio (BCR)}

Pendapatan nelayan ditinjau dari banyaknya ikan hasil tangkapan setelah melakukan operasi penangkapan. Hasil tangkapan masing-masing unit teknologi penangkapan ikan kurau memiliki nilai jual yang berkualitas tinggi. Unit teknologi penangkapan jaring kurau memiliki pendapatan bersih tertinggi dari ketiga jenis unit teknologi penangkapan lainnya yaitu: jaring kurau Rp. 219.930.00 diikuti jaring tangsi sebesar Rp. 84.810.000, rawai sebesar Rp. 58.998.000 dan pancing sebesar Rp. 21.414.000. Pendapatan usaha masingmasing unit teknologi penangkapan ikan kurau dapat dilihat pada (Tabel 7).

Pendapatan merupakan nilai uang yang didapat dari hasil penjualan produksi ikan yang dipengaruhi oleh besarnya jumlah ikan hasil tangkapan dan harga yang terbentuk pada saat didaratkan. Pendapatan pada usaha penangkapan dengan multigear diperoleh dari jumlah produksi setiap ikan dikalikan dengan harga rata-rata ikan (Wismaningrum 2013).

Nilai BCR unit teknologi penangkapan ikan kurau tertinggi yaitu jaring kurau sebesar $(1.57>1)$, diikuti rawai $(1.19>1)$, pancing $(1.09>1)$ dan jaring tangsi $(1.07>1)$. Dengan demikian unit teknologi 
penangkapan ikan kurau di Pambang Pesisir dapat dikategorikan layak untuk dikembangkan karena memiliki nilai $\mathrm{BCR}>1$. Nilai BCR masing-masing unit teknologi penangkapan ikan kurau disajikan pada (Tabel 8).

\section{Investasi usaha}

Investasi usaha merupakan pengeluaran sejumlah uang atau menyimpan uang dengan harapan suatu saat mendapat keuntungan finansial. Menurut Irham (2009) menyatakan bahwa investasi adalah seluruh biaya yang dikeluarkan untuk proyek sampai proyek tersebut beroperasi untuk menghasilkan benefit. Contoh investasi dalam penangkapan ikan yaitu pembelian berupa barang seperti alat tangkap, kapal, coolbox/palkah dan mesin. Unit teknologi penangkapan ikan kurau memiliki investasi berbeda-beda, investasi tertinggi yaitu jaring kurau sebesar Rp.284.200.00, diikuti jaring tangsi sebesar Rp.161.200.000, rawai sebesar Rp.100.900.000 dan pancing sebesar Rp.45.700.000. Investasi usaha masing-masing unit teknologi penangkapan ikan kurau selengkapnya dapat dilihat pada (Tabel 9).

Analisis kelayakan usaha unit teknologi penangkapan ikan kurau

Analisis kelayakan usaha digunakan untuk melihat kelayakan usaha penangkapan ikan kurau layak atau tidak layak untuk dikembangkan. Hasil analisis kelayakan usaha dari beberapa unit teknologi penangkapan ikan kurau di Pambang Pesisir dapat dikatakan layak dan berpotensi untuk dikembangkan.

Berdasarkan (Tabel 10) menunjukkan bahwa seluruh unit teknologi penangkapan ikan kurau di Pambang Pesisir layak untuk dikembangkan, hal itu dapat dilihat dari nilai NPV yang positif dan nilai IRR melebihi bunga suku bank yang ditetapkan. Nilai
NPV tertinggi yaitu jaring kurau sebesar Rp. 163.087.528 dengan pengembalian modal selama 1 tahun 6 Bulan 39 hari dan terendah pancing Rp.4.255.619 dengan pengembalian modal selama 2 tahun 8 bulan 22 hari. Nilai IRR unit penangkapan ikan kurau juga terbilang baik, dengan nilai IRR lebih besar dari suku bunga bank yang ditetapkan, yaitu kredit mikro bank RiauKepri (11.69\%) dan bank BRI (19\%) selama 10 tahun. Nilai IRR tertinggi yaitu jaring kurau sebesar 53.70\% dan terendah jaring tangsi sebesar 23.51\%.

Unit teknologi penangkapan jaring kurau memiliki nilai finansial yang lebih baik dari ketiga alat tangkap lainnya. Menurut Purnomo et al. (2013) menyatakan bahwa usaha perikanan jaring kurau di Desa Pambang Pesisir menunjukkan keuntungan dalam jangka pendek, dengan masa pengembalian modal awal (PP) sangat singkat yaitu hanya 20 bulan dan laju pengembalian finansial (IRR) 54\%.

Unit teknologi penangkapan jaring kurau dilihat dari aspek ekonomi sangat menguntungkan, karena hasil tangkapannya yang banyak dalam satu kali operasi/trip. Dari aspek teknis alat tangkap jaring kurau memiliki wilayah penangkapan yang luas, teknologi yang modern dan pengoperasiannya terbilang mudah serta tidak banyak menghabiskan tenaga. Tetapi jika dilihat dari aspek biologi jaring kurau memiliki by catch cukup tinggi, ancaman terhadap biodiversity tinggi dan rendahnya selektivitas, hal itu dapat berdampak terhadap populasi ikan kurau. Menurut Syaifuddin (2008) menyatakan bahwa ikan kurau ini telah mengalami lebih tangkap (over exploited) dan over fishing (Rengi 2015). Oleh karena itu pengelolaan perikanan tangkap di Pambang Pesisir ke depan haruslah mempertimbangkan aspek biologi, teknis dan sosial ekonomi dalam memilih unit teknologi penangkapan ikan kurau berkelanjutan. 
Tabel 6. Permodalan unit teknologi penangkapan ikan kurau

\begin{tabular}{clrrr}
\hline No & Jenis Alat Tangkap & $\begin{array}{c}\text { Biaya Tetap } \\
(\mathbf{R p )}\end{array}$ & $\begin{array}{c}\text { Biaya Tidak Tetap } \\
(\mathbf{R p )}\end{array}$ & Total Modal (Rp) \\
\hline 1 & Jaring Kurau & 112.800 .000 & 291.270 .000 & 404.070 .000 \\
2 & Jaring Tangsi & 57.600 .000 & 72.870 .000 & 130.470 .000 \\
3 & Rawai & 32.400 .000 & 150.870 .000 & 183.270 .000 \\
4 & Pancing & 17.100 .000 & 63.510 .000 & 80.610 .000 \\
\hline
\end{tabular}

Tabel 7. Pendapatan unit teknologi penangkapan ikan kurau

\begin{tabular}{clcrr}
\hline No & $\begin{array}{c}\text { Unit Penangkapan } \\
\text { Ikan Kurau }\end{array}$ & $\begin{array}{c}\text { Pendapatan } \\
\text { Kotor (Rp) }\end{array}$ & Total Cost (Rp) & $\begin{array}{c}\text { Pendapatan Bersih } \\
\text { (Rp) }\end{array}$ \\
\hline 1 & Jaring Kurau & 624.000 .000 & 404.070 .000 & 219.930 .000 \\
2 & Jaring Tangsi & 215.280 .000 & 130.470 .000 & 84.810 .000 \\
3 & Rawai & 242.268 .000 & 183.270 .000 & 58.998 .000 \\
4 & Pancing & 105.144 .000 & 80.610 .000 & 24.534 .000 \\
\hline
\end{tabular}

Tabel 8. Nilai BCR unit teknologi penangkapan ikan kurau

\begin{tabular}{clccc}
\hline No & Jenis Alat Tangkap & BCR & Nilai & Keterangan \\
\hline 1 & Jaring Kurau & 1.57 & $>1$ & Layak \\
2 & Jaring Tangsi & 1.07 & $>1$ & Layak \\
3 & Rawai & 1.19 & $>1$ & Layak \\
4 & Pancing & 1.09 & $>1$ & Layak \\
\hline
\end{tabular}

Tabel 9. Investasi usaha unit teknologi penangkapan ikan kurau

\begin{tabular}{clccc}
\hline No & Jenis Alat Tangkap & $\begin{array}{c}\text { Jumlah Biaya } \\
\text { (Rp) }\end{array}$ & Penyusutan (Rp) & $\begin{array}{c}\text { Persentase } \\
\text { Penyusutan }\end{array}$ \\
\hline 1 & Jaring Kurau & 284.200 .000 & 40.300 .000 & $7.05 \%$ \\
2 & Jaring Tangsi & 161.200 .000 & 16.700 .000 & $9.65 \%$ \\
3 & Rawai & 100.900 .000 & $10,365,000$ & $9.73 \%$ \\
4 & Pancing & 45.700 .000 & 4.950 .000 & $9.23 \%$ \\
\hline
\end{tabular}

Tabel 9. Kelayakan usaha unit teknologi penangkapan ikan kurau di Pambang Pesisir

\begin{tabular}{clrcc}
\hline No & Jenis Alat Tangkap & \multicolumn{1}{c}{ NPV (Rp) } & IRR & Paybcak Period \\
\hline 1 & Jaring Kurau & 163.087 .528 & $53.70 \%$ & 1 tahun 7 Bulan 9 hari \\
2 & Jaring Tangsi & 11.434 .897 & $23.51 \%$ & 2 tahun 8 bulan 23 hari \\
3 & Rawai & 19.030 .559 & $30.83 \%$ & 2 tahun 4 bulan 8 hari \\
4 & Pancing & 4.255 .619 & $24.90 \%$ & 2 tahun 8 bulan 22 hari \\
\hline
\end{tabular}




\section{KESIMPULAN DAN SARAN}

\section{Kesimpulan}

Karakteristik unit teknologi penangkapan ikan kurau di Pambang pesisir untuk jaring kurau dan jaring tangsi menggunakan webbing berbahan PA (polyamide) dan tangsi (nilon), mesh sizeyang digunakan berukuran 2.5-7 inci dan ukuran kapal berkisar 6 sampai $12 \mathrm{~m}$. Rawai dan pancing menggunakan tali utama berbahan nilon 110, mata pancing bernomor 6 dan 7, dengan umpan ikan parang-parang, tenggiri, layur, udang dan lomek. Ukuran kapal yang digunakan berkisar 6-8 m. Hasil analisis ekonomi (finansial) menunjukkan bahwa seluruh unit teknologi penangkapan ikan kurau di Pambang pesisir layak untuk dikembangkan dengan nilai NPV yang positif, nilai IRR melebihi bunga suku bank yang ditetapkan dan BCR $>1$.

\section{Saran}

Sebagai saran diharapkan nelayan lebih mengelola keuanganya untuk lebih efisien dan tepat guna dalam penggunaannya. Kemudian untuk penelitian lanjutan diharapkan adanya analisis yang mempertimbangkan faktor-faktor yang memengaruhi aspek teknis dan ekonomi.

\section{UCAPAN TERIMA KASIH}

Penulis mengucapkan banyak terima kasih kepada Kementerian Pendidikan dan Kebudayaan Republik Indonesia (KEMENDIKBUD RI) selaku lembaga yang telah membiayai penelitian ini, sehingga penulis dapat menyelesaikan penelitiannya.

\section{DAFTAR PUSTAKA}

[DKP] Dinas Kelautan dan Perikanan. 2014. Data Statistik Perikanan dan Kelautan Kabupaten Bengkalis Provinsi Riau. Bengkalis (ID).

Charles AT. 2001. Sustainable Fishery System. London (GB). Blackwell Science Ltd.

De Wysiecki AM, Jaureguizar AJ, Cortés. F. 2016. The Importance Of Environmental Drivers On The Narrownose Smoothhound Shark (Mustelus Schmitti) Yield In A SmallScale Gillnet Fishery Along The Southern Boundary Of The Rio De La Plata Estuarine Area. Fish
Res, 186(1):345-355.

Hermansyah AP, Pramonowibowo I. 2013. Perbandingan Analisis Finansial Usaha Penangkapan Payang Rumpon Dan Payang Lampu Di Pelabuhan Perikanan Pantai (PPP) Tawang Kabupaten Kendal. JFRUMT, 2(4):3039.

Irham L dan Yogi. 2009. Studi Kelayakan Bisnis. Jakarta (ID). Penerbit Poliyamawidya Pustaka.

Pratama FA, Boesono H, Dwi HT. 2012. Analisis Kelayakan Finansial Usaha Penangkapan Ikan Menggunakan Panah dan Bubu Dasar di Perairan Karimunjawa. JFRUMT, 1(1):22-31.

Purnomo. Bustari, Huri E. (2013). Manajemen Operasi Penangkapan Ikan dan Kelayakan Ekonomi Gillnet (Jaring Kurau) Nelayan Desa Pambang Kabupaten Bengkalis. JOM, 1(1):1-13.

Rengi P, Tang UM, Syahza A, Ikhwan SY. 2015. Status, Exploration Potential and Resource Management of Kurau (Eleutheronema Tetradactylum) Fish In Overfishing Area (Case Study In Bengkalis District, Riau Province). IJREES, 3(2):8-13.

Rohani S, Yulinda E, Hamid H. 2015. Analisis Usaha Penangkapan dengan Alat Tangkap Gombang di Desa Meskom Kecamatan Bengkalis Kabupaten Bengkalis Provinsi Riau. JOM, 2(4):112.

Syaifuddin. 2008. Pendugaan Potensi dan Pola Musim Penangkapan Ikan Kurau (Eleutheronema tetradactylum) di Perairan Pulau Bengkalis. Lembaga Penelitian Universitas Riau. Pekanbaru (ID).

Umar H. 2003. Studi Kelayakan dalam Bisnis Jasa. Jakarta (ID). PT Gramedia Pustaka Utama.

Wijopriono. Nugroho D, Sadhotomo B. 2012. Tren Pemanfaatan Sumberdaya Ikan Kurau (Polinimidae) di Perairan Bengkalis Selat Malaka. JPPI, 18( 4):205-212.

Wismaningrum KEP, Ismail, Fitri ADP. 2013. Analisis Finansial Usaha Penangkapan One Day Fishing dengan Alat Tangkap Multigear di Pelabuhan Perikanan Pantai (PPP) Tawang Kabupaten Kendal. JFRUMT, 2(3):263-272.

Wiyono ES. 2011. Reorientasi Manajemen Perikanan Skala Kecil. Bogor (ID). Pemanfaatan dan Pengelolaan Sumberdaya Perikanan Laut Berkelanjutan, New Paradigm in 
Marine Fisheries, Departemen PSP FPIK IPB. Hlm 23-35.

Yafiz M, Sondita MFA, Soemakaryo S, Monintja DR. 2009. Analisis Finansial Usaha Penangkapan Ikan dalam Model Perbaikan Kesejahteraan Nelayan di Kabupaten Rokan Hilir Provinsi Riau. JPK, 14(1):81-92. 